ДВНЗ “Тернопільський державний медичний університет імені І. Я. Горбачевського МОЗ Украӥни”

\title{
СИМУЛЯЦІЙНЕ НАВЧАННЯ СТУДЕНТІВ ЯК ОДИН ІЗ ПЕРСПЕКТИВНИХ МЕТОДІВ ФОРМУВАННЯ ТА ВДОСКОНАЛЕННЯ ПРОФЕСІЙНИХ ХІРУРГІЧНИХ НАВИЧОК У МАЙБУТНІХ ЛІКАРІВ
}

D. B. Fira

\author{
I. Horbachevsky Ternopil State Medical University
}

\section{SIMULATION TEACHING OF STUDENTS AS ONE OF PROMISING TECHNIQUES OF FUTURE DOCTORS' PROFESSIONAL SKILLS IN SURGERY FORMATION AND IMPROVEMENT}

\begin{abstract}
Мета роботи - дослідити взаємозв'язок між симуляційними методами навчання та формуванням професійних навичок у студентів.

Основна частина. У роботі проаналізовано ефективність використання Міжкафедрального навчально-тренінгового центру симуляційного навчання ДВНЗ “Тернопільський державний медичний університет імені І. Я. Горбачевського МОЗ України” у відпрацюванні практичних навичок студентів з дисципліни “Загальна хірургія”. Засвоєння матеріалу і відпрацювання навичок студентами на фантомах дозволяють залучати їх до виконання певних маніпуляцій на пацієнтах під ретельним контролем з боку викладачів (промивання шлунка, катетеризація сечового міхура, перев'язки та ін.). Опанування на симуляторах таких навичок, як внутрішньовенна та внутрішньом'язова ін'єкції, навичок серцево-легеневої реанімації необхідне для навчання студентів на будь-якій клінічній кафедрі.

Симуляційний центр, створений у ТДМУ, забезпечує теоретичну частину, вивчення практичних випадків, відеосесію, тренінг мануальних навичок та вмінь, роботу на анімальних моделях, спеціалізовані тренінги, участь у конференціях. Для адекватного засвоєння навичок виділено понад 10 \% від загального навчального навантаження.

Висновок. Використання симуляційних методів значно покращує якість презентації навчального матеріалу й ефективність його засвоєння студентами, збагачує зміст навчального процесу, підвищує мотивацію до навчання та дозволяє об’єктивно оцінити досягнутий рівень професійної підготовки кожного студента.
\end{abstract}

Ключові слова: професійна компетентність; симуляційне навчання; клінічне мислення; мотивація до навчання.

The aim of the work - to investigate the relationship between simulation techniques of training and the formation of students' professional skills.

The main body. The effectiveness of the "Interdepartmental educational and training center of simulation education" use at the I. Horbachevsky Ternopil State Medical University within students' practical skills in "General Surgery” training is analyzed in the article. Mastering the material and students' skills training on phantoms, allows to involve them to perform certain manipulations on patients under careful control by the teachers (gastric lavage, catheterization of the bladder, bandages, etc.). Capturing skills in simulators such as intravenous and intramuscular injection, cardiopulmonary resuscitation skills is required to train students at any clinical department. The simulation center created at TSMU provides a theoretical part, the study of practical cases, video sessions, training of manual skills and abilities, work on animated models, specialized trainings, participation in conferences. More than $10 \%$ of the total academic load is allocated for the adequate skills learning.

Conclusion. The use of stimulation methods greatly improves the quality of the presentation of the teaching material and the efficiency of its acquisition by students, enriches the content of the educational process, increases the motivation to study and allows to evaluate the level of professional training of each student objectively.

Key words: professional competence; simulation training; clinical thinking; motivation to study.

Вступ. Формування професійної компетентності у студентів є складним процесом, що включає

(С) Д. Б. Фіра в себе безліч компонентів. Метою вищої освіти є підготовка високоосвічених і конкурентоспроможних фахівців на основі формування у них знань, 
умінь, навичок, а також активізації інтелектуального, морального, творчого і фізичного розвитку особистості $[3,4]$.

Сучасні тенденції медичної освіти пропонують використання методик симуляційного навчання, щоб досягти максимально можливого ступеня реалізму при імітації різноманітних клінічних ситуацій, а також відпрацювання технічних навичок й алгоритму дій при окремих діагностичних та лікувальних маніпуляціях. Симуляція - це навчання, яке дозволяє замінити реальний досвід або розширити його за допомогою керованого досвіду, передбачає інтерактивне занурення у природу процесів, процедур та явищ моделювання реальних ситуацій [5, 7].

На сьогодні не викликає сумнівів доцільність використання симуляції для навчання студентів. Для реалізації цього методу існують два шляхи: навчання на окремих кафедрах, використовуючи основні форми симуляційного навчання, або створення навчально-тренінгових центрів практичної медичної підготовки студентів. Оптимальним є формування центрів фантомно-симуляційного навчання в медичних навчальних закладах. Спрямованість на особистісно-орієнтоване навчання, як одна з глобальних тенденцій розвитку сучасної освіти, передбачає підготовку конкурентоспроможних фахівців з високим рівнем загальнокультурних і професійних компетенцій.

Досвід використання фантомів та симуляторів, яке має місце у багатьох навчальних закладах, показав підвищення інтересу у студентів до навчання та якості засвоєння матеріалу [6, 9, 10]. Клінічне моделювання допомагає в реальному часі сформувати навик практичної роботи лікаря без наслідків для здоров’я пацієнта. У зв’язку з цим, організація фантомного та симуляційного навчання студентів $є$ необхідним напрямком в освітньому процесі.

Мета роботи - дослідити взаємозв'язок між симуляційними методами навчання та формуванням професійних навичок у студентів.

Основна частина. На кафедрі загальної хірургії ДВНЗ “Тернопільський державний медичний університет імені І. Я. Горбачевського МОЗ України” навчаються студенти 3-го курсу медичного факультету. При реалізації освітніх програм на кафедрі постійно вводяться та використовуються сучасні освітні технології з симуляційними методами, максимально наближеними до реальності, що потребує прийняття студентами правильних рішень та відпрацювання певних практичних навичок залежно від клінічної ситуації. Для вирішення поставлених завдань на кафедрі продовжують застосовуватися різні засоби навчання: ситуаційні задачі, створені на основі реальних історій хвороб хворих, банк навчальних посібників і методичних рекомендацій, мультимедійні презентації, комп’ютерні технології, навчальні відеофільми, віртуальні програми, а також впровадження сучасних методів профілактики, діагностики та лікування відповідно до стандартних методів доказової медицини. Це дозволяє студентам відпрацювати практичні навички по обстеженню хірургічного хворого та виконання окремих лікарських маніпуляцій. Маючи теоретичну підготовку, володіючи практичними навичками і відпрацювавши віртуальний алгоритм діагностики, лікування та надання невідкладної допомоги, студент проводить безпосередню курацію хворого в стаціонарі і доповідає перед групою. Засвоєння матеріалу і відпрацювання навичок студентами на фантомах дозволяють залучати їх до виконання певних маніпуляцій на пацієнтах під ретельним контролем з боку викладачів (промивання шлунка, катетеризація сечового міхура, перев’язки та ін.).

Симуляційне навчання має цілу низку переваг на відміну від традиційної системи підготовки, а саме можливість об’єктивної реєстрації параметрів виконаних професіональних дій з метою досягнення високого рівня підготовки кожним майбутнім спеціалістом, напрацювання навичок без ризику для пацієнтів і незалежність від роботи клінік. На відміну від традиційної системи підготовки, при якій молодий лікар може досконально знати теоретичну частину тієї чи іншої маніпуляції та не мати практичного досвіду, використання симуляційних технологій дозволяє відпрацювати та закріпити той чи інший алгоритм практичних дій і в майбутньому використати набуті знання при роботі з пацієнтами.

Саме симулятори можуть багаторазово і точно відтворити важливі клінічні сценарії і можливість адаптувати навчальну ситуацію під кожного студента [1, 2]. Значною перевагою симуляційного тренінгу, порівняно з традиційною системою підготовки, є можливість багаторазового відпрацювання певних вправ і дій, доведення їх до автоматизму, а також забезпечення об’ єктивного контролю якості надання медичної допомоги за результатами виконання тренінгу $[1,8]$.

Опанування на симуляторах таких навичок, як внутрішньовенна та внутрішньом'язова ін'єкції, навичок серцево-легеневої реанімації необхідне для навчання студентів на будь-якій клінічній 
кафедрі. Однак існує низка маніпуляцій, виконати які в екстремальних умовах повинен лікар кожної спеціальності. Під цим розуміють навички кваліфікованої тимчасової та кінцевої зупинки кровотечі, проведення транспортної іммобілізації, трахеотомію й трахеостомію та деякі інші невідкладні втручання.

Симуляційний центр, створений у ТДМУ, забезпечує теоретичну частину, вивчення практичних випадків, відеосесію, тренінг мануальних навичок та вмінь, роботу на анімальних моделях, спеціалізовані тренінги, участь у конференціях. У Тернопільському державному медичному університеті навчання хірургічних навичок починається з 2-го курсу. На 2-му курсі перевага віддається показовому виконанню маніпуляцій викладачем, а потім багаторазовому повторенню виконання процедури студентом. Пізніше, на 2-му та 3-му курсах у процесі вивчення дисципліни “Загальна хірургія”, викладачі формують навички надання першої допомоги в екстремальних умовах: проведення транспортної іммобілізації, зупинка кровотечі, основи реанімації та інтенсивної терапії, десмургія, у зв’язку з чим виділяються години для академічних занять. На 3-му курсі у процесі вивчення дисципліни перелік набутих навичок із використанням симуляційних технологій значно розширюється. Це заходи щодо

\section{Список літератури}

1. Альберг Г. Відпрацювання ендохірургічних практичних навичок з використанням віртуальних технологій / Г. Альберг // Віртуальні технології в медицині. 2009. - № 1. - С. 7.

2. Дозорнов М. Г. Сучасні проблеми навчальних центрів та шляхи їх вирішення / М. Г. Дозорнов // Віртуальні технології в медицині. - 2010. - № 2. - С. 4-6.

3. Симуляційне навчання в медицині: міжнародний та вітчизняний досвід / В. В. Артьоменко, С. С. Семченко, О. С. Єгоренко [та ін.] // Одеський медичний журнал. 2015. - № 6. - С. 67-74.

4. Корда М. М. Шляхи імплементації Закону України “Про вищу освіту” в Тернопільському державному медичному університеті / М. М. Корда, А. Г. Шульгай, I. М. Кліщ // Медична освіта. - 2015. - № 2. - С. 34-39.

5. Gaba D. M. The future vision of simulation in healthcare / D. M. Gaba // Quality and Saferyin Health Care. - 2004. 13 (Suppl. 1). - P. 2-10.

6. Інноваційні педагогічні технології: теорія та практика використання у вищій школі : монографія / догляду за ранами різного характеру, місцева анестезія, дренування ранових порожнин, десмургія, накладання хірургічних швів, пункція гнійників та інші хірургічні маніпуляції. Для адекватного засвоєння навичок виділено понад 10 \% від загального навчального навантаження.

3 нашої точки зору, застосування симуляторів та манекенів одночасно на кафедрах та в центрах симуляційного навчання тільки розширить клінічне мислення студентів та дозволить відпрацювати базові практичні навички з дисципліни. Окрім того, створює необхідні умови для забезпечення глибокої міжпредметної інтеграції та чіткої клінічної орієнтації викладання дисциплін, з послідовним опануванням студентами практично орієнтованих знань і навичок, готовності самостійно виконувати типові задачі лікарської діяльності.

Висновки. Використання симуляційних методів значно покращує якість презентації навчального матеріалу й ефективність його засвоєння студентами, збагачує зміст навчального процесу, підвищує мотивацію до навчання.

Впровадження симуляційного методу навчання $€$ новим напрямом у сучасній вітчизняній школі підготовки висококваліфікованих конкурентоспроможних кадрів, становлення медичного працівника як професіонала й цілісної особистості.

I. I. Доброскок, В. П. Коцур, С. О. Нікітчина [та ін.] ; Переяслав-Хмельниц. держ. пед. ун-т ім. Г. Сковороди, Ін-т пед. освіти і освіти дорослих АПН України. - ПереяславХмельницький : Вид-во С. В. Карпук, 2008. - 284 с.

7. Имитационное обучение в системе непрерывного медицинского профессионального образования / под ред. чл.-кор. РАМН П. В. Глыбочко. - М. : Изд-во Первого МГМУ им. И. М. Сеченова, 2012. - 120 с.

8. Развитие профессионального врачебного мышления / А. В. Бутвиловский, Е. А. Кармалькова, В. Э. Бутвиловский, И. С. Кармалькова // Медицинский журнал. - 2013. № 2. - С. 157-158.

9. Мещерякова М. А. Обучение профессиональным мануальным умениям и оценка уровня их сформированности у студентов медицинских вузов / М. А. Мещерякова, Н. С. Подчерняева, Л. Б. Шубина // Врач. - 2007. № 7. - С. 81-83.

10. Шубина Л. Б. Имитационное обучение в медицине / Л. Б. Шубина, М. А. Мещерякова, И. М. Сон // Качество образования. - 2011. - № 4. - С. 42-46. 


\section{References}

1. Alberg, H. (2009). Vidpratsiuvannia endokhirurhichnykh praktychnykh navychok z vykorystanniam virtualnykh tekhnolohii [Development of endosurgical practical skills using virtual technologies]. Virtualni tekhnolohii $v$ medytsyni - Virtual Technologies in Medicine, 1, 7 [in Ukrainian].

2. Dozornov, M.H. (2010). Suchasni problemy navchalnykh tsentriv ta shliakhy yikh vyrishennia [Modern problems of educational centers and ways of their solution]. Virtualni tekhnolohii v medytsyni - Virtual Technologies in Medicine, 2, 4-6 [in Ukrainian].

3. Artiomenko, V.V., Semchenko, S.S., Yehorenko, O.S., Novikov, D.A., Karakonstantyn, D.F., \& Berlinska, L.I. (2015). Symuliatsiine navchannia v medytsyni: mizhnarodnyi ta vitchyznianyi dosvid [Simulation study in medicine: international and national experience]. Odeskyi medychnyi zhurnal - Odesa Medical Journal, 6, 67-74 [in Ukrainian].

4. Korda, M.M., Shulhai, A.H., \& Klishch, I.M. (2015). Shliakhy implementatsii Zakonu Ukrainy «Pro vyshchu osvitu» v Ternopilskomu derzhavnomu medychnomu universyteti [Ways of Implementation of the "The Higher Educational Act of Ukraine” in Ternopil State Medical University]. Medychna osvita - Medical Education, 2, 34-39 [in Ukrainian].

5. Gaba, D. M. (2004). The future vision of simulation in health care. Quality and Safety in Health Care, 13 (Suppl. 1), 2-10.
6. Dobroskok, I.I., Kotsur, V.P., \& Nikitchyna, S.O. (2008). Innovatsiini pedahohichni tekhnolohii: teoriia ta praktyka vykorystannia u vyshchii shkoli: monohrafiia [Innovative pedagogical technologies: theory and practice of use in higher school: monography]. Pereiaslav-Khmelnytskyi: Vyd-vo S.V. Karpuk [in Ukrainian].

7. Glybochko, P.V. (Ed.) (2012). Imitatsionnoye obucheniye $v$ sisteme nepreryvnogo meditsinskogo professionalnogo obrazovaniya [Simulative training in the system of continuous professional medical education]. Moscow: Izd-vo Pervogo MGMU im. I.M. Sechenova [in Russian].

8. Butvilovskiy, A.V., Karmalkova, E.A., Butvilovskiy, V.E., \& Karmalkova, I.S. (2013). Razvitiye professionalnogo vrachebnogo myshleniya [Development of professional medical thinking]. Meditsinskiy zhurnal (Respubliki Belarus) - Medical Journal (Republic of Belarus), 2, 157-158 [in Russian].

9. Meshcheryakova, M.A., Podchernyayeva, N.S., \& Shubina, L.B. (2007). Obucheniye professionalnym manualnym umeniyam i otsenka urovnya ikh sformirovannosti u studentov meditsinskikh vuzov [Training for professional skills and assessment of their level of formation among medical students]. Vrach - Doctor, 7, 81-83 [in Russian].

10. Shubina, L.B., Meshcheryakova, M.A., \& Son, I.M. (2011). Imitatsionnoye obucheniye v meditsine [Simulative education in medicine]. Kachestvo obrazovaniya - Quality of Education, 4, 42-46 [in Russian]. 